Research, part of a Special Feature on Restoring Riverine Landscapes

\title{
Environmental Flows: Striking the Balance between Development and Resource Protection
}

\author{
Jackie King $^{1}$ and Cate Brown ${ }^{2}$
}

\begin{abstract}
Management of scarce water resources through the use of environmental flows, particularly in developing countries in data-poor arid areas, raises many scientific challenges. These include transforming hydrological data into an ecologically relevant format, providing quantified predictions of river responses to flow change, describing the impacts of river change on common-property users of the rivers, providing the information in a format that decision makers can use, and guiding monitoring and adaptive management. Each of these challenges emerged in South Africa during the last two decades, when rivers and other aquatic ecosystems were enhanced in stature from having no rights to their own water to being one of only two sectors with a right to water; the other sector is for basic human needs. This paper outlines the challenges, how they are being addressed in South Africa, and perceptions of what remains to be done.
\end{abstract}

Key Words: environmental flows; South Africa; holistic approach; biophysical change; river condition; common-property use; decision support system

\section{INTRODUCTION}

Increasing demands for water are degrading rivers worldwide, resulting in a loss of the vital goods and services they provide. Nowhere is the problem more urgent than in developing countries in arid climates, in which fast-growing human populations are reliant on very limited water resources and often on a range of other river resources as well. Many of these countries acknowledge that environmental protection must be a component of their management of water but have limited data and understanding of their aquatic ecosystems with which to achieve this (King et al. 2003).

South Africa began to address the problem of flowrelated degradation of rivers in the 1980s. First, aquatic ecosystems, which formerly had no rights to their own water, were recognized as competing users of this water. Their status was further enhanced in the 1998 Water Act, in which they were recognized as the "base of the resource" and became one of only two sectors with a right to water; the other one is basic human needs. In the late 1980s, aquatic scientists were tasked with defining the water requirements for ecosystem maintenance (King and Louw 1998, King et al. 2003). The problems involved in this undertaking were not trivial but appear to be common globally: few relevant data, a limited understanding of the nature and function of river ecosystems, limited funds, and a lack of scientists with relevant skills. Water managers in South Africa, where only about half of the people have adequate access to potable water, could not wait until these shortcomings had been overcome. Issues related to water supply had to be addressed, and decisions on water resources would be made, with or without scientific input.

Responding to this, in a major shift in thinking and approach, the nation's water scientists moved to provide advice on water allocations for ecosystem maintenance based on limited knowledge. New scientist-management interactions developed based on the following criteria: 
1. Contribute scientifically using best available knowledge.

2. Adhere to the precautionary principle of making conservative assessments in situations in which uncertainty is high.

3. Learn by doing.

4. Practice adaptive management.

The available methods for environmental flow assessments at that time were of three main kinds (Tharme 2003):

1. hydrological approaches based on simple hydrological statistics,

2. hydraulic-rating methods based on simple relationships between flow and the hydraulic conditions in the river, and

3. habitat-rating methods based on the relationships between hydraulic conditions and favored hydraulic habitat for representative or target species.

None of these met the South African requirement for an approach to guide management of the condition of the complete river ecosystem. New holistic approaches were therefore developed in real dam-development projects, including the Building Block Methodology (King and Louw 1998) and Downstream Response to Improsed Flow Transition or DRIFT (Brown and Joubert 2003, King et al. 2003). For example, DRIFT consists of four modules:

1. a biophysical module designed to maximize understanding of the river ecosystem within the project's time and financial constraints and predict the effects of flow change on the river,

2. a social module designed to maximize understanding of how people use the river and its resources and predict how they would be affected by the changing river,

3. a scenario-building module in which the predicitve capacity is used to compile scenarios of river change and the impact on people, and

4. an economic module in which the costs as well as the benefits of development can be summarized.

Close liaison with Australian scientists following a similar holistic approach (Arthington et al. 2000, Brizga et al. 2002, Tharme 2003) has allowed a continued fruitful sharing of ideas. Habitat-rating methods tend to be concentrated in the northern hemisphere and in developing countries aided by the United States and Europe, whereas the holistic approaches are centered in the southern hemisphere, e.g., South Africa and Australia, and are the most rapidly growing set of methods globally at the present time (Tharme 2003).

This paper outlines major scientific challenges that emerged in South Africa during the process of method development, the ways in which they have been addressed, and perceptions of what remains to be done. The focus in this paper is on holisitic methods and, for simplicity, specifically on:

1. perennial rivers, although environmental water for the maintenance of ephemeral rivers, wetlands, estuaries, and groundwater systems is receiving similar attention;

2. water quantity, although water quality is an essential aspect of environmental water and is receiving equal attention in terms of method development; and

3. the development of water resources through, for instance, dams or abstractions and the consequent potential degradation of the targeted aquatic system, although the approach described here can also be used for flow restoration as part of river rehabilitation.

\section{CHALLENGE 1: TRANSFORM HYDROLOGICAL DATA INTO A FORM THAT ECOLOGISTS CAN USE}

Decades of measured flow data and the capacity through modern hydrological models to simulate daily flow data can together produce massive hydrological data sets. The summary data produced 
from these data sets aid water managers in planning water supply but may be difficult for ecologists to interpret for their own purposes.

For example, flow duration curves (FDCs) are constructed from data covering the chosen period of a day, month, season, year, or any other period by ranking discharge values from highest to lowest and using these to create a curve that illustrates the percentage of the chosen time period during which any discharge is equaled or exceeded. Ecologists shown two FDCs of the present flow regime and a potential one with the flow regime changed might be asked how or if the planned flow change will affect the river ecosystem. It may be pointed out that the highest and lowest flows will still occur and "just the bit in the middle will change slightly" (Fig. 1). With the information in this form it is extremely difficult for an ecologist to assess how the flow change will affect the functioning of the river ecosystem, but a rearrangement of the data can help.

\section{Flow categories}

The first step is to identify the different components of the flow regime that are thought to play a role in maintaining river ecosystems. In South Africa, for instance, where river flow is markedly different between the wet and dry seasons and most rivers are relatively short with flashy flood peaks and few extensive floodplains, 10 flow categories have been found useful (Table 1). Twenty or more years of measured or simulated daily flow data can be allocated to the flow categories, with every day's data accounted for in one of them. Summary data from these flow categories then allow a new perspective on the river, in terms that can help ecological understanding (Table 1). Other kinds of rivers might have different kinds or numbers of flow categories. A very large floodplain river, for instance, might have a single slow increase and decrease in flow over the whole wet season rather than many intra-annual floods, whereas an ephemeral river would have no flow in part of the dry season. The more unpredictable the flow regime, the longer the record needed to obtain a reasonable summary of conditions.

Summary data such as those in Table 1 can be produced to compare the past, present, and potential future flow regimes of a particular river. This provides far more information to an ecologist than would FDCs produced from the same data. For instance, not only is it immediately obvious from Table 2 that Scenario 2 would degrade the river more than Scenario 1, with 53\% of the mean annual flow remaining in the river vs. $10 \%$, but it is also clear how each ecologically relevant flow category will change. Scenario 1 is a muted version of the natural flow regime and is likely to cause a moderately low level of change in the river while allowing $47 \%$ of its natural mean annual flow to be abstracted for offstream purposes. In contrast, Scenario 2 would remove almost all flow variability from the river and instead provide year-round, almost constant low flows interspersed with very rare overtopping floods.

Such information on potential flow changes has triggered directed research on how each flow category contributes to river maintenance, based on some initial perceptions of flow-ecosystem links (Table 3). This enables more precise predictions of river change, such as for Scenario 2 (Table 2), in which it was predicted that there would be (1) an increase in nutrient concentrations, algae, and rooted aquatic vegetation and in epilithon and/or sediments, with some clogging of the spaces between the rocks (hyporheos), and (2) a loss of refugia with a possible decrease in the abundance of key fish and eel species (C. A. Brown and J. M. King, unpublished manuscript).

\section{CHALLENGE 2: PROVIDE HOLISTIC QUANTITATIVE PREDICTIONS OF HOW FLOW MANIPULATIONS CAN CHANGE RIVERS, IN SITUATIONS IN WHICH DATA ARE FEW AND LEVELS OF UNCERTAINTY HIGH}

Creating a structured understanding of the hydrology of the system, as above, is an essential first step in a holistic environmental flow assessment. This then becomes the foundation upon which predictions of future flow-related change are built. In South Africa, it is important for these predictions to be: (1) holistic, (2) quantitative, and (3) feasible even when only limited data are available. Each of these characteristics is discussed below. 
Fig. 1. Present-day and predicted flow duration curves constructed from $20 \mathrm{yr}$ of daily flow data.

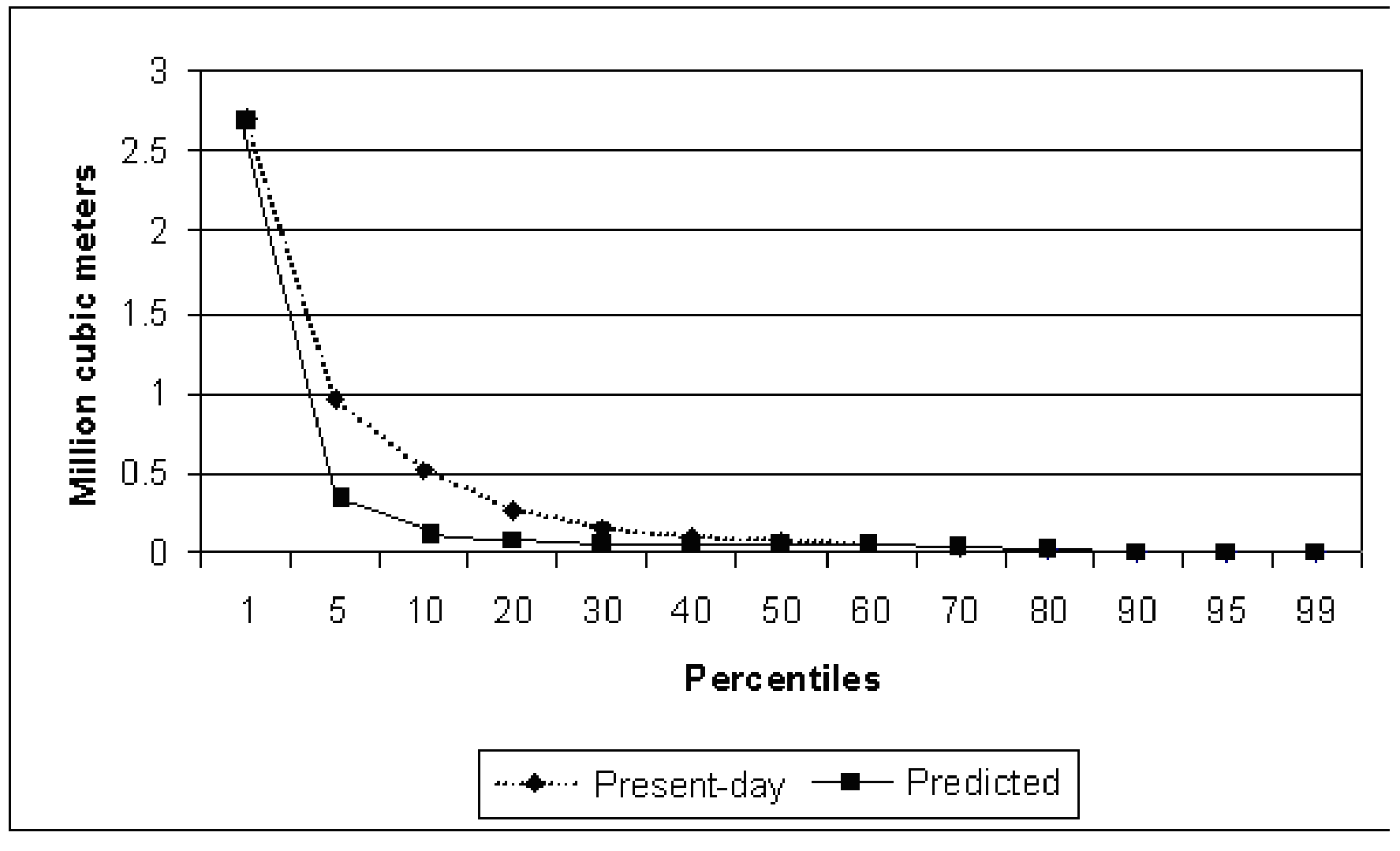

\section{Holistic predictions}

The most recent type of environmental flow assessment (EFA) method is termed holistic (Tharme 2003) because of its underlying philosophy that:

1. river ecosystems in any condition other than pristine should be actively managed,

2. all major abiotic and biotic components of the ecosystem constitute the unit to be managed, and

3. within the abiotic components, the full spectrum of flows and their temporal and spatial variability constitute the flows to be managed.

Advising on such holistic management requires a multidisciplinary team working within a structured scientific process such as the Building Block Methodology (BBM) or the Downstream Response to Imposed Flow Transition (DRIFT). South African flow assessment teams now consist of one or more specialists in the fields of surface water hydrology, hydraulic/hydrodynamic modeling, fluvial geomorphology, water quality, botany, ichthyology, and the ecology of aquatic invertebrates, plus, when necessary, groundwater hydrology, sedimentology, plankton, herpetofauna, water birds, water-dependent mammals, terrestrial wildlife, and aquatic microbiology. The team works together within the framework of the chosen holistic process to achieve two aims: (1) to study the river in question and develop an understanding its nature and functioning within the time and finanical limitations of the project and, based on this understanding, (2) to develop, for use in scenario creation, a predictive capacity of how the river might change if the flow regime were changed. 
Table 1. Summary statistics of the present near-natural flow regime at a study site in the Molenaars River, Western Cape, South Africa (Brown and King 2002).

\begin{tabular}{llcc}
\hline \hline $\begin{array}{l}\text { Category } \\
\text { number }\end{array}$ & Flow category & $\begin{array}{c}\text { Discharge } \\
\left(\mathrm{m}^{3} / \mathrm{s}\right)\end{array}$ & $\begin{array}{c}\text { Average number } \\
\text { of } \\
\text { events per year }\end{array}$ \\
\hline 1 & $\begin{array}{l}\text { Dry-season low } \\
\text { flows } \\
\text { Wet-season low } \\
\text { flows }\end{array}$ & $0.02-4.08$ & $\ldots$ \\
2 & $\begin{array}{l}\text { Intra-annual flood } \\
\text { size class 1 }\end{array}$ & $0.36-12.02$ & 6 \\
3 & $\begin{array}{l}\text { Intra-annual flood } \\
\text { size class 2 }\end{array}$ & $4.50-9.99$ & 3 \\
4 & $\begin{array}{l}\text { Intra-annual flood } \\
\text { size class 3 }\end{array}$ & $10-20$ & 3 \\
5 & $\begin{array}{l}\text { Intra-annual flood } \\
\text { size class 4 }\end{array}$ & $21-41$ & 2 \\
6 & $1: 2$ year flood & $42-84$ & $\ldots$ \\
7 & $1: 5$ year flood & & $\ldots$ \\
8 & $1: 10$ year flood & 94 & $\ldots$ \\
10 & $1: 20$ year flood & 146 & $\ldots$ \\
\hline
\end{tabular}

The specialists use their own study and analytical techniques to develop an understanding of the river ecosystem. Their research focuses on the kinds of flow-ecosystem relationships illustrated in Table 3 . To establish these relationships, all the data collected have to be linked to flow: if the link is not clear, the ability to predict flow-related change in the river is not enhanced. This approach may require that the specialists completely reorient their knowledge; those with no EFA experience may have an extensive knowledge of the river but be unable to use most of it to predict how the river could respond to flow changes. One example of developing an understanding of flow-ecosystem relationships has been the recognition of a similar series of riparian vegetation zones up the riverbanks in very different parts of southern Africa (Boucher 2002, Boucher and Tlale 2000, Steward et al. 2002). These zones correlate well with the return period of flows of different magnitude (Table 4), suggesting that in some way specific flows help maintain specific zones.

Whereas flow duration curves (FDCs) alone are not very helpful for an ecological interpretation of hydrological data, when used in combination with hydraulic models they can produce new insights on river ecosystems, such as the proportion of time that any one vegetation zone on a river is inundated (Fig. 2). A first estimate of the inundation-exposure regime that a zone experiences can be calculated, and judicious use of FDCs for different time periods will indicate when the exposure and inundation periods are. Understanding this correlation, and thus the inundation conditions that the vegetation zone is exposed to and therefore possibly needs, allows a first tentative prediction of whether a change in the flow regime might cause the zone to shrink, 
Table 2. Possible new flow regimes linked to a planned dam for the site described in Table 1. MAF $=$ mean annual flow, env flow $=$ environmental flow released downstream for river maintenance, $\mathrm{P}=$ present, $\mathrm{A}=$ absent (Brown and King 2002).

\begin{tabular}{|c|c|c|c|c|}
\hline $\begin{array}{l}\text { Flow comp- } \\
\text { onent }\end{array}$ & $\begin{array}{l}\text { Present day } \\
\left(\mathrm{m}^{3} / \mathrm{s}\right)\end{array}$ & Number/yr & $\begin{array}{c}\text { Flow Scenario } \\
1\left(\mathrm{~m}^{3} / \mathrm{s}\right)\end{array}$ & $\begin{array}{c}\text { Flow Scenario } \\
2\left(\mathrm{~m}^{3} / \mathrm{s}\right)\end{array}$ \\
\hline $\begin{array}{l}\text { Dry-season } \\
\text { low flows }\end{array}$ & $0.20-4.08$ & $\ldots$ & $0.20-0.60$ & 0.15 \\
\hline $\begin{array}{l}\text { Wet-season } \\
\text { low flows }\end{array}$ & $0.36-12.02$ & $\ldots$ & $0.10-3.00$ & 0.4 \\
\hline $\begin{array}{l}\text { Intra-annual } \\
\text { flood } 1\end{array}$ & $4.5-9.99$ & 6 & 5 & 1 \\
\hline $\begin{array}{l}\text { Intra-annual } \\
\text { flood } 2\end{array}$ & $10-20$ & 3 & 2 & \\
\hline $\begin{array}{l}\text { Intra-annual } \\
\text { flood } 3\end{array}$ & $21-41$ & 3 & 2 & \\
\hline $\begin{array}{l}\text { Intra-annual } \\
\text { flood } 4\end{array}$ & $42-84$ & 2 & 2 & \\
\hline 1:2 yr flood & 94 & $\ldots$ & $\mathrm{P}$ & A \\
\hline 1:5 yr flood & 146 & $\ldots$ & $\mathrm{P}$ & A \\
\hline $\begin{array}{l}1: 10 \mathrm{yr} \\
\text { flood }\end{array}$ & 181 & $\ldots$ & $\mathrm{P}$ & A \\
\hline $\begin{array}{l}1: 20 \mathrm{yr} \\
\text { flood }\end{array}$ & 187 & $\ldots$ & $\mathrm{P}$ & $\mathrm{P}$ \\
\hline $\begin{array}{l}\% \text { natural } \\
\text { MAF as env } \\
\text { flow }\end{array}$ & $\ldots$ & $\ldots$ & 53 & 10 \\
\hline
\end{tabular}

expand, adjust to a higher or lower place on the bank, or completely disappear. Such predictions are equally possible for development or restoration projects.

Similar tentative relationships based initially on simple conceptual models are presently being developed between flow categories and channel morphology (e.g., Dollar 2005), fish (e.g., Arthington et al. 2003), water quality (e.g., Malan and Day 2002), and invertebrates (e.g., Ractliffe and Dallas 2004), and could usefully be developed for all other ecosystem components.
Combining all this knowledge to produce synthesized predictions of complete ecosystem response to flow changes is complex. Facilitators who understand the assessment method aid team deliberations, but essentially the specialists are running an ecosystem model in their heads. To help them, the process of building a complete picture of responses adheres to the following sequence, with each specialist building her/his predictions of reachlevel changes on the ones earlier in the sequence, using a series of representative sites along the river:

1. The hydrologist decribes the changes that could occur in each surface flow category. 
Table 3. Some possible links between flow categories and ecosystem functioning in Western Cape rivers, South Africa.

\begin{tabular}{ll}
\hline \hline Flow category & Ecosystem link \\
\hline Dry-season low flows & $\begin{array}{l}\text { Maintain perenniality and thus wet habitat for survival of aquatic species, trigger emergence } \\
\text { of some insect species }\end{array}$ \\
Wet-season low flows & Maintain wetbank vegetation and fast-flow habitat \\
Intra-annual flood 1 & Trigger fish spawning in mid-dry season, flush out poor-quality water \\
Intra-annual flood 2 & Trigger fish spawning in early dry season, flush out poor-quality water \\
Intra-annual flood 3 & Sort sediments by size, maintain physical heterogeneity, flush riffles, scour cobbles \\
Intra-annual flood 4 & $\begin{array}{l}\text { Sort sediments by size, maintain physical heterogeneity, flush tree seedlings from edge of } \\
\text { active channel }\end{array}$ \\
$1: 2$ yr flood & Maintain tree line on banks, scour out sedimented areas in active channel \\
$1: 5$ yr flood & $\begin{array}{l}\text { Maintain lower part of tree/shrub vegetation zone on banks, deposit sediments in riparian } \\
\text { zone }\end{array}$ \\
$1: 10$ yr flood & Maintain channel, reset physical habitat, maintain middle part of tree/shrub zone \\
$\geq 1: 20$ yr flood & Maintain channel, reset physical habitat, maintain top part of tree/shrub zone
\end{tabular}

2. The geohydrologist, if relevant and particularly for ephemeral rivers, predicts changes in subsurface flow and the height and location of the water table.

3. The hydraulic modeler converts the surface flows to hydraulic conditions.

4. The sedimentologist and fluvial geomorphologist predict how the channel could respond to these changed hydraulic conditions, including by in-filling or flushing of pools, sedimentation or scouring of riffles, changes in mobility and size-sorting of different-sized bed particles, loss or gain of flood-terrace deposits, and the accumulation or loss of muddy deposits within the active channel.

5. The water-quality specialist predicts how the chemical and thermal regime of the river could change, including changes in the concentrations of specified nutrients and dissolved solids.
6. With all abiotic predictions now made, the vegetation specialist is the first to describe expected biotic responses by predicting how each vegetation zone could change location, width, or some other characteristic, and which plant species may become more or less abundant.

7. Knowing how the abiotic and vegetative components of habitat could change, the invertebrate specialist predicts shifts in invertebrate communities, including the change in abundance of species that pose health risks.

8. If relevant, one or more plankton specialists and microbiologists predict changes in these communities, including parasites, disease organisms, and toxic algae.

9. The fish ecologist predicts changes in fish communities, including shifts in community composition, species abundances, and condition. 
Table 4. Possible links between vegetation zones and flow categories in southern African rivers (modified from Boucher 2002).

\begin{tabular}{lll}
\hline \hline Vegetation zone & Type of vegetation & Correlations with flow categories \\
\hline Aquatic & Algae and submerged macrophytes & Perennials maintained by dry-season low flows \\
Lower wetbank & Mosses, ferns, sedges & Wet-season low flows \\
Upper wetbank & Sedges, reeds, herbs, grasses & Class 1, 2, and 3 intra-annual floods \\
Lower dynamic & $\begin{array}{l}\text { Pioneer communities, annuals, young } \\
\text { trees and occasional older ones }\end{array}$ & $\begin{array}{l}\text { Reached by Class 3 and 4 intra-annual floods; too high } \\
\text { for wetbank vegetation, floods too regularly for trees to }\end{array}$ \\
Tree and shrub & Trees and shrubs & $\begin{array}{l}\text { Tree line maintained by 1:2 yr floods; whole tree and } \\
\text { shrub zone reached by 1:2 up to 1:20 yr floods }\end{array}$ \\
Back dynamic & $\begin{array}{l}\text { Outer limit of riparian species, semi- } \\
\text { terrestrial }\end{array}$ & $\begin{array}{l}\text { Reached by >1:20 yr flood } \\
\end{array}$ \\
& &
\end{tabular}

10. If relevant, specialists on amphibians, reptiles, water birds, semi-aquatic mammals, and other river-dependent wildlife predict how they would be affected.

The process can be used to predict the response to change in a single flow category or sequentially in all parts of the flow regime.

\section{Quantitative predictions}

Although specialists may feel able to make predictions as per the above sequence in terms of the direction and general nature of change, they may be far more reluctant to predict the timing and extent of change. Most may be willing, however, to use a mild form of quantification in the form of severity ratings (Table 5). Five severity levels of change work well; fewer provide insufficient distinction of change, and more can be counterproductive by causing indecision about which level to choose.

The severity of response to any one flow change may differ among ecosystem variables. To address this and provide details about what is changing, the predictions can be structured by using lists of all the ecosystem variables that could respond to flow changes. The itemized variables can be gathered into indicator lists (Table 6) compiled for each discipline. Priorities are assigned to these lists, and it is expected that, over time, they will become increasingly generic, in the sense that they will cover any variable that could be relevant in any river, and thus amenable to inclusion in drop-down menus in flow-assessment software packages. As the team members consider a possible flow change, they provide a "severity of change" value for each item on their indicator lists and an indication of whether this would involve an increase or decrease in abundance or area or concentration, thereby creating an extensive data set of flow-response couplets. A flow assessment of, for instance, five sites using six specialists could produce more than 40,000 predictive flow-response couplets (King et al. 2003). The use of these couplets in scenario creation is described below.

\section{Few data, high uncertainty}

In every flow assessment there are likely to be fewer data than the specialists would wish for and high levels of uncertainty in their predictions. This will probably be the case even in relatively well-studied systems, because the data appropriate for an EFA may not have been collected. One way of managing 
Fig. 2. Use of a flow duration curve to estimate the inundation exposure regime of riparian vegetation zones. Q stands for quantity.

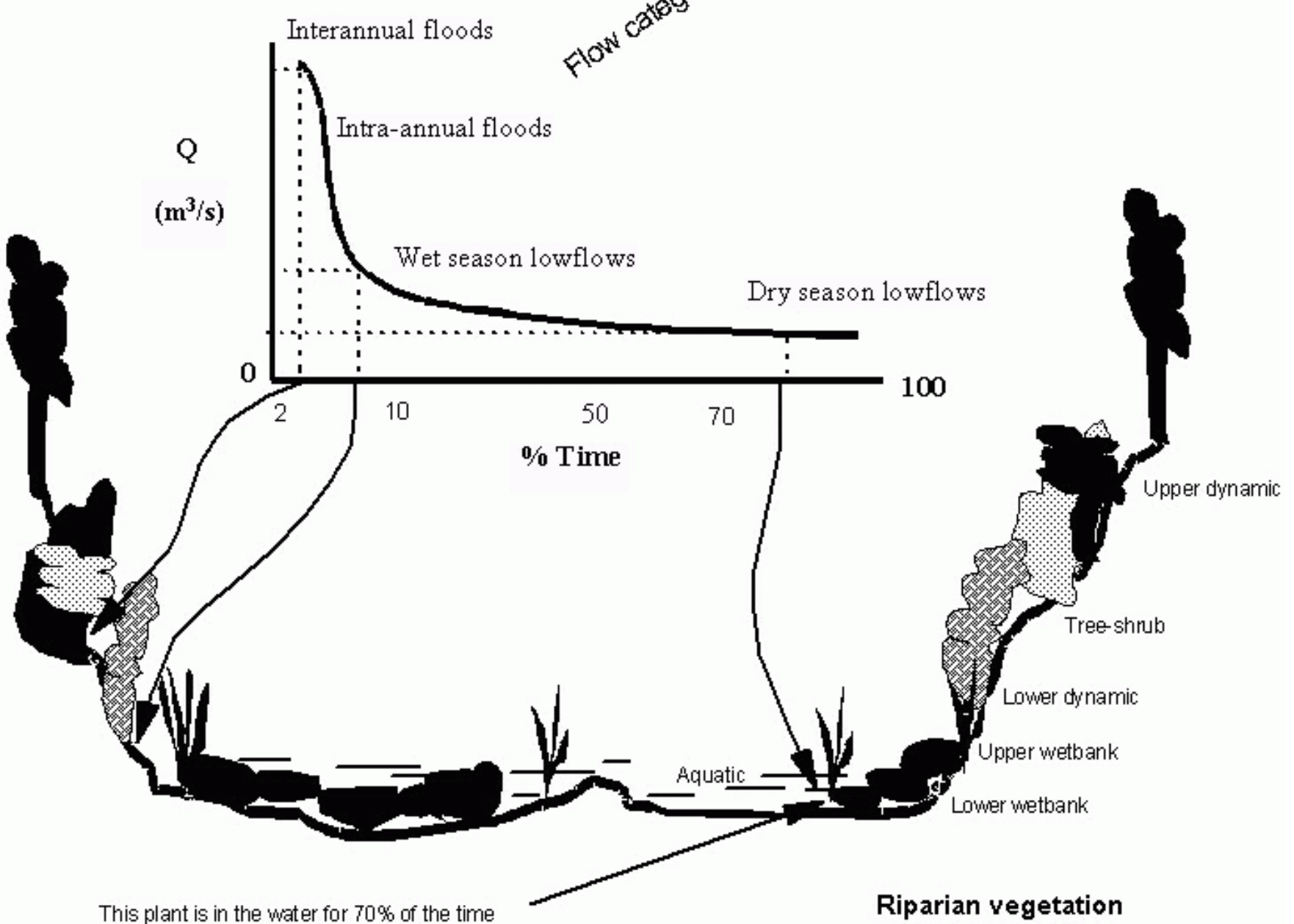

this has been mentioned: to opt for predictions based on ratings of change rather than fully quantified changes. Other techniques found to be essential are as follows:

1. In each discipline, use highly experienced specialists who have hands-on knowledge of the river under consideration. They can counteract data limitations to some extent by providing inputs based on international literature and a general understanding of the river.
2. Further extend the use of severity ratings by allowing predictions to be based on ranges rather than single ratings. An indicator list item predicted to decrease in abundance with a severity rating of 2-4 indicates a higher level of uncertainty than one predicted to decrease with a rating of 2 .

3. Adopt the philosophy of "learning by doing," so that a lack of complete understanding is not a reason for doing nothing. Instead, go forward using the techniques above to register 
Table 5. Severity ratings for predictions of change in abundance, area, or concentration of ecosystem variables (King et al. 2003).

\begin{tabular}{ll}
\hline \hline Severity rating & Severity of change \\
\hline 0 & None \\
1 & Negligible \\
2 & Low \\
3 & Moderate \\
4 & High \\
5 & Very high \\
\hline
\end{tabular}

the level of confidence in the predictions and to identify priority areas for research that will enhance the confidence in the predictions.

\section{CHALLENGE 3: DESCRIBE HOW THESE PREDICTED RIVER CHANGES CAN AFFECT COMMON-PROPERTY RURAL USERS OF THE RIVERS}

In developing countries, there are likely to be very high numbers of rural people who depend on river resources for their livelihoods. Fish, frogs, and water birds may be their main protein source; wild vegetables and herbs from the aquatic and riparian zones may provide vital nutrients and medicines; and riparian trees provide firewood and construction materials that, in semi-arid areas, are scarce away from the river. In addition, rivers are prominent in health, cultural, religious, and recreational aspects of their lives. Until very recently, water resource developers have not taken into account the possible downstream impacts of river changes on such people (McCully 1996, World Commission on Dams 2000).

To assess these impacts, a two-part approach to environmental flow assessments (EFAs) has been adopted in South Africa. Common-property livelihood users are included in the direct EFA procedure discussed in this section, whereas they and all other users of the river are included in a stakeholder process linked to the planned watermanagement proposal.

Holistic EFA methods such as Downstream Response to Imposed Flow Transition (King et al. 2003) include a socioeconomic module focusing on livelihood users that is just as prominent as the biophysical module. The specialists involved may be in the fields of public health, livestock health, anthropology, sociology, water use, and resource economics. Their tasks are similar to those of the biophysical team: (1) to understand how the people use the river and (2) to predict how the described river changes could affect them. Close liaison from the outset between the biophysical and socioeconomic teams ensures that all the ecosystem attributes identified by the people as important in some aspect of their lives, e.g., fish species X, tree species Y, pest insect species Z, sand for building, are specifically included in river studies and indicator lists so that the potential effects of flow changes on these attributes can be predicted. All predictions of ecosystem change are explained to the social team so that they can develop an understanding with the riparian people of how they may be affected. Indicator lists (Table 7) and severity ratings are again used to structure the predictions of these impacts. 
Table 6. Examples of entries in the biophysical indicator lists for a study in Lesotho.

\begin{tabular}{|c|c|c|}
\hline Discipline & Indicator list entry & Links to flow \\
\hline Sedimentology & $\begin{array}{l}\text { Deposition of colloidal } \\
\text { material }\end{array}$ & $\begin{array}{l}\text { Minimum velocity for maintenance of movement of colloidal material in } \\
\text { main channel }=0.05 \mathrm{~m} / \mathrm{s} \text { (Metsi Consultants } 2000 \mathrm{c} \text { ) }\end{array}$ \\
\hline Water quality & Nutrient levels & $\begin{array}{l}\text { Nutrient levels in pools increase under low flow conditions, water in pools } \\
\text { flushed by }>\text { Class } 2 \text { floods (Metsi Consultants } 2000 d \text { ) }\end{array}$ \\
\hline Vegetation & Chenopodium album & $\begin{array}{l}\text { Mostly in the wetbank vegetation zone, whose width is reduced by a } \\
\text { decrease in the volume and variability of low flows and in the number of } \\
\text { Class } 1 \text { floods (Metsi Consultants } 2000 a \text { ) }\end{array}$ \\
\hline Fish & Maloti Minnow & $\begin{array}{l}\text { Inhabits quiet }(<0.2 \mathrm{~m} / \mathrm{s}) \text { shallow }(0.21-0.30 \mathrm{~m}) \text { waters in rocky reaches } \\
\text { with high water quality (Arthington et al. } 2003)\end{array}$ \\
\hline Invertebrates & Simulium medusaeforme & $\begin{array}{l}\text { Filter feeder on cobbles in slow }(0.01-0.49 \mathrm{~m} / \mathrm{s}) \text {, often polluted water } \\
\text { (Metsi Consultants } 2000 e)\end{array}$ \\
\hline
\end{tabular}

\section{CHALLENGE 4: PROVIDE THE INFORMATION IN A FORM THAT DECISION MAKERS CAN USE}

Equaling the need to better understand the relationships between flows and river ecosystems and between river change and human impacts is the need to express this understanding in terms that decision makers can use. Three main requirements that have become apparent are the ability to:

1. provide a range of options of what the future could be like, using scenarios of potential river changes and social impacts;

2. provide simple summaries of each scenario of river change in a context that the decision makers can relate to; and

3. express the financial implications of each scenario in terms of both impacts and costs for compensation or mitigation purposes and benefits, e.g., increased hydroelectric power generation or crop production.

Not all of these may be needed in any one assessment.

\section{Providing scenarios}

Early holistic approaches to environmental flow assessment (EFA) were prescriptive: a desired river condition was recommended, and the EFA to maintain it was described (King et al. 2000). Although this approach is still appropriate when a specific target condition has been decided upon, decision makers considering a possible development such as a dam increasingly voice a preference to consider several options, that is, a series of scenarios with different kinds of flow regimes that would result in different river conditions and thus different impacts on people.

The predictive flow-change/ecosystem-response couplets provided by the biophysical specialists can be used to build a database in which they can be mixed in many permutations to produce scenarios. The Downstream Response to Imposed Flow Transition (DRIFT), for example, does this through the Microsoft optimization package SOLVER (Brown and Joubert 2003). The individual entries in the database consist of predictions, guided by the indicator lists, of river change in response to a series of levels of change in each flow category. Predictions for each change in any one flow category are made under the assumption that none of the other flow categories are changing. Thus, for example, for a river that currently has an average 
Table 7. Examples of entries in the socioeconomic indicator lists for the Lesotho study.

\begin{tabular}{lll}
\hline \hline Discipline & $\begin{array}{l}\text { Indicator list } \\
\text { entry }\end{array}$ & $\begin{array}{l}\text { Examples of flow-related concerns (and links to biophysical } \\
\text { disciplines) }\end{array}$ \\
\hline $\begin{array}{l}\text { Sociology (re- } \\
\text { source use) }\end{array}$ & $\begin{array}{l}\text { Pools for } \\
\text { ceremonial use }\end{array}$ & $\begin{array}{l}\text { Pool depth and size (gemorphologist), water quality (aquatic chemist } \\
\text { and microbiologist), control of pest invertebrates and plants including } \\
\text { toxic algae (invertebrate and vegetation specialists; Metsi Consultants } \\
2000 f)\end{array}$
\end{tabular}

Public health Diarrheal disease and skin and eye diseases

\begin{abstract}
Increase in colloidal material allows diarrheal disease-causing organisms such as Giardia to remain in the river for longer, thus increasing the chances of people becoming infected either through contact or consumption (sedimentologist, aquatic chemist, microbiologist; Metsi Consultants 2000g)
\end{abstract}

Animal health Simulium chS. chutteri is a significant potential blackfly pest of livestock utteri (invertebrate specialist; Metsi Consultants 2000h)

per year of six Intra-annual Flood 1 events, the specialists may be asked to predict how the river would change if there were only four per year, or two, or none, in each case with no other flow changes occurring. The predicted impact on each item on each indicator list at each flow-change level becomes a separate database entry linked to the volume of water encompassed in that change level.

To create the scenarios, a volume of water that could be dedicated to river maintenance is entered into SOLVER, which selects one change level from each of the 10 flow categories. The selection is based on the severity ratings, with the aim of achieving the lowest overall severity-rating score for a river targeted for development, thus minimizing ecosystem degradation from present condition, or the highest overall score for a river that is being rehabilitated, thus maximizing the ecosystem shift back toward its natural state. The output is thus a flow regime that optimizes river condition for the entered volume of water. Alternatively, a desired river condition could be entered, and the flow regime to achieve it would be described. The scenarios so produced also provide all the linked text of the original flow-response predictive couplets, which should be synthesized and assessed for anomalies by an experienced river ecologist and adjusted if necessary.

\section{Summarizing river impacts}

The complex scientific descriptions of possible river change may be more detailed than decision makers can use. Although several kinds of summary data can be prepared, they may lack some simple indication of how much worse or better than its present one the condition of the river will be in each scenario and how well this adheres to international good practice. DRIFT uses the SOLVER database and DRIFT-CATEGORY software to predict the category (Table 8) of the condition of the river in each scenario (Fig. 3). The borders between condition categories are transitions rather than hard lines, and their positions are not well established. At present, DRIFT defines them by a tentative set of rules based on severity ratings, which will be adjusted if experience suggests this is necessary (Brown and Joubert 2003). Thus, despite the uncertainty about boundaries, it is possible to make a first structured and transparent estimate of whether or not a scenario could push a river through to another condition category. This is information that can be used by water managers. In South Africa, for instance, the 1998 Water Act stipulates that new water developments may not degrade a river below its present condition category, and so scenarios that are likely to do this can be identified at an early prefeasibility level of planning. 
Table 8. Ecological status categories (from Kleynhans 1999).

\begin{tabular}{ll}
\hline \hline Category & Description \\
\hline A & Unmodified, natural \\
B & $\begin{array}{l}\text { Largely natural with few modifications; a small change in natural habitats and biota may have taken } \\
\text { place, but the ecosystem functions are essentially unchanged }\end{array}$ \\
C & $\begin{array}{l}\text { Moderately modified; a loss and change of natural habitat and biota have occurred, but the basic } \\
\text { ecosystem functions are still predominantly unchanged }\end{array}$ \\
D & $\begin{array}{l}\text { Largely modified; a large loss of natural habitat, biota, and basic ecosystem functions has occurred } \\
\text { E }\end{array}$ \\
F & $\begin{array}{l}\text { Modensive loss of natural habitat, biota, and basic ecosystem functions } \\
\text { an almost complete loss of natural habitat and biota. In the worst instances, the basic ecosystem } \\
\text { functions have been destroyed, and the changes are irreversible. }\end{array}$
\end{tabular}

\section{Estimating compensation costs for riparian subsistence users}

Social specialists use the detailed scenarios of river change to predict the probable severity of impacts on riparian subsistence users. Compensation for these impacts is a complex matter, because it should address not only direct losses of resources, but also the replacement costs of alternative resources and mitigation costs to ensure that there is no deterioration in human and livestock health profiles. Only the direct compensation costs of lost resources are addressed here.

Decision makers may need to know the value of river resources that could be lost or gained as a river changes. To this point in the process described above, because of scientific uncertainty, these changes have only been expressed using severity ratings. This is not amenable to economic assessment, and so, outside the scientific process, a percent value could be applied to the severity ratings (Table 9) to make it possible to calculate the percentage of each resource that would be lost or gained, and the probable monetary value in each case. It is emphasized that this is an economic manipulation that goes beyond the point at which scientists may feel comfortable, but it does allow a first estimate of the direct livelihood costs of development. Using the conversions, the gain or loss of any goods that the river provides, such as fish or reeds, or services that can be directly measured, such as assimilation capacity for pollutants, can be costed and summarized per scenario.

\section{The wider decision-making arena}

The EFA process described above provides information on the ecological and social costs of basin development that was not available to decision makers in the past. Ignoring these details distorts the true economic costs of development. In the top block of Table 10, for instance, Scenario I represents a level of development close to the present situation and Scenario VI a high development level. In the past, decisions may have been based mainly on consideration of the benefits, with Scenario VI likely appearing the most attractive. The EFA, however, informs on the possible hidden costs of development in the bottom block, making it clear that Scenario VI may in fact be a less attractive option and that a trade-off between development and resource protection should perhaps be sought at some lower level of development that will maintain the river in a healthier condition. 
Fig. 3. Plot of declining ecosystem integrity with loss of flow volume for a site in the Molenaars River created using DRIFT-CATEGORY and with the integrity score based on the averaged severity ratings of change. The river is presently a Category $\mathrm{B}$ river, starting point at 0 on the integrity score axis, and is predicted to decline through Categories $\mathrm{C}, \mathrm{D}$, and $\mathrm{E}$ at the flow volumes shown. The categories are explained in Table 8.

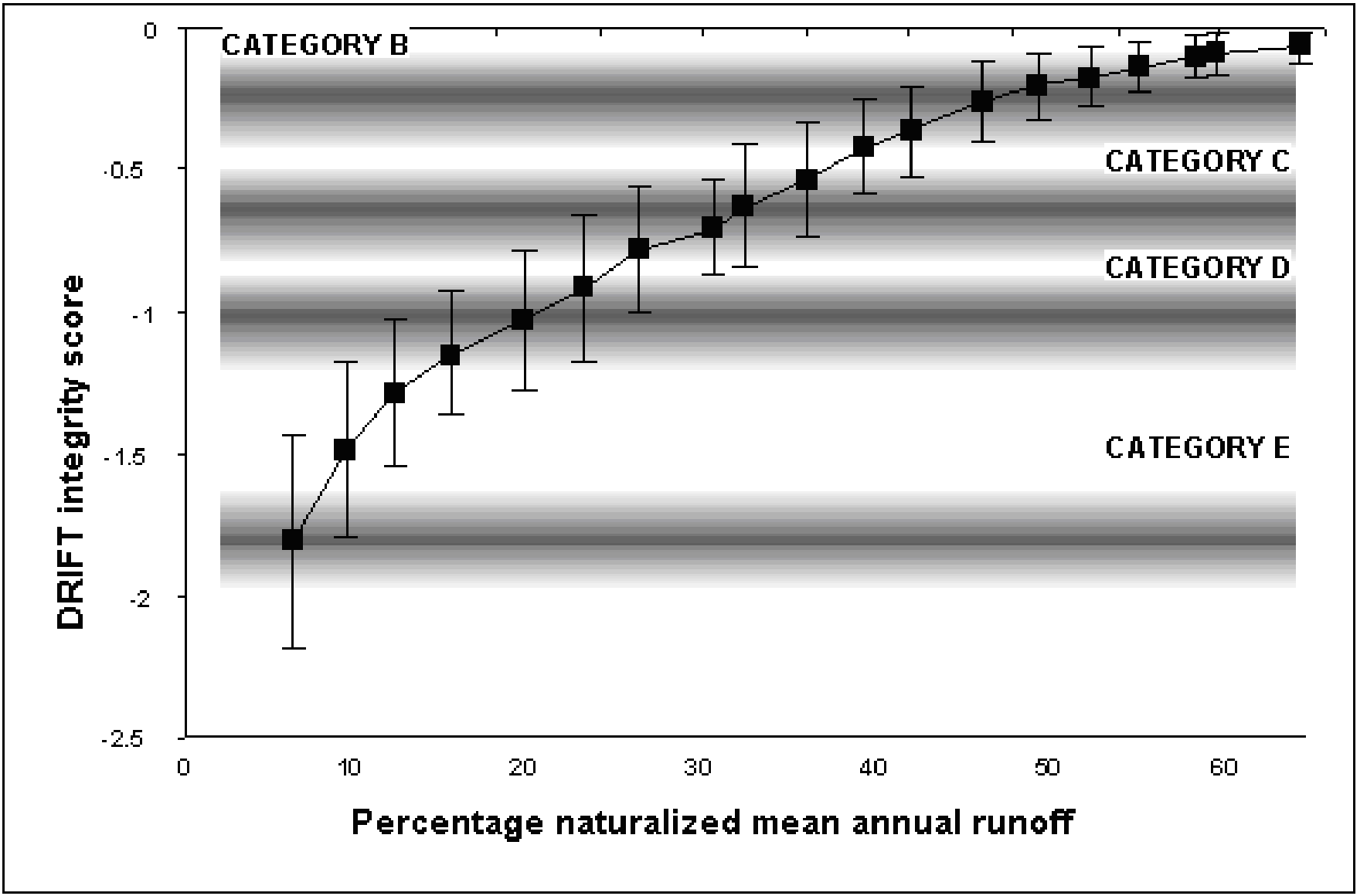

Rivers in different parts of a country can be held at different condition levels (Tables 8 and 10) that reflect local priorities for resource protection and development. Deciding on the condition level for each major watercourse in South Africa is an essential first step in allocating the water needed for resource protection as required by the 1998 Water Act. To further this, the South African Department of Water Affairs and Forestry is developing a process to bring together the following components for any one river system (DWAF 2005):

1. an analysis of the benefits of water-source development (top block in Table 10),
2. an analysis of the development costs as provided by the EFA (bottom block in Table $10)$,

3. input on the acceptability of each scenario from a comprehensive stakeholder process, and

4. a decision-making process by which all the above are considered and a decision is made in a structured and transparent way.

Although this process is still in its infancy, several 
Table 9. Severity ratings for predictions of change in abundance of biophysical features and a possible conversion to percentages (after King et al. 2003).

\begin{tabular}{llll}
\hline \hline Severity rating & Severity of change & $\begin{array}{l}\text { Equivalent loss } \\
(\% \text { decrease in abundance })\end{array}$ & $\begin{array}{l}\text { Equivalent gain } \\
\text { (\% increase in abundance) }\end{array}$ \\
\hline 0 & None & No change & No change \\
1 & Negligible & $0-20 \%$ loss & $1-25 \%$ gain \\
2 & Low & $21-40 \%$ loss & $26-67 \%$ gain \\
3 & Moderate & $41-60 \%$ loss & $68-250 \%$ gain \\
4 & Severe & $61-80 \%$ loss & $251-500 \%$ gain \\
5 & Critically severe & $81-100 \%$ loss & $\begin{array}{l}501 \% \text { gain to } \infty ; \\
\text { up to pest proportions }\end{array}$
\end{tabular}

studies that are contributing to its design have used an early form of it: the Palmiet River (Brown et al. 2000), the Elands River (Dollar 2003), and the Thukela River (DWAF 2004). The process, which is to be finalized within the next year, is intended to be structured, transparent, and capable of comparing all major relevant benefits and costs of development. It will consider both tangible and intangible, i.e., not amenable to monetary evaluation, attributes of rivers; be able to consider inputs from all stakeholders on scenario acceptability; and be able to identify the optimal trade-off between resource protection and development.

In a wider arena, the DRIFT approach can easily be adapted to address specific management questions. It has already been adapted for several other applications, e.g., to develop a "mini-DRIFT" method for use in developing countries with few resources (Steward et al. 2002); to assess possible changes to releases from a dam on the Zambesi to enhance the benefits to a range of stakeholders including hydroelectric power operators, subsistence fishermen, sugar cane farmers, and Cape buffalo; and to inform development planning of the Lower Mekong Basin. The latter two applications are very recent, and no public documents are available to date.

\section{CHALLENGE 5: GUIDE MONITORING AND ADAPTIVE MANAGEMENT}

Once the trade-offs have been assessed and a basin development level decided upon, the river condition that level describes becomes the desired state for the river, and the flow regime encompassed within that scenario becomes the environmental flow (EF). The implementation of that EF is a vital next step; if that fails, all the scientific, legislative, and other developments to that point fail also. EF monitoring and adaptive management are two interlinked parts of implementation. In South Africa, monitoring of EFs and subsequent adaptive management are in their early stages, and the following provides an outline of some relevant developments and a few comments.

\section{Monitoring}

EF monitoring has two immediate purposes: (1) to ascertain that the agreed-upon flow is being delivered to selected control points along the river and (2) to ensure that it is achieving the desired condition. A wider purpose is to allow scientists to assess the accuracy of their predictions. Each scenario consists of a series of predictions; it is an experiment or hypothesis that will be tested by the delivery of the EFs. Monitoring is a vital part of the EF process, because, as scientists step forward to 
Table 10. Hypothetical example of the matrix of information that could be developed for each part of a river basin. The indicators would differ from river to river, and the numbers used here are merely to illustrate possible trends in indicator status. The numbers do not constitute a scoring system; rather, the specialists' reports should be referred to for the detail represented by each numbered cell. Decisions should be based on this underlying information. Ratings of change: $1=$ negligible change from present; $2=$ low change; $3=$ moderate change; $4=$ high change; $5=$ very high change. Negative values indicate either that the river ecosystem is moving away from its natural state, i.e. degrading, or a compensation/mitigation cost.

\begin{tabular}{|c|c|c|c|c|c|c|c|}
\hline \multirow[t]{2}{*}{ Indicators } & \multicolumn{7}{|c|}{ Flow scenarios reflecting increasing levels of basin development } \\
\hline & Present & $\mathrm{I}$ & II & III & IV & $\mathrm{V}$ & VI \\
\hline \multicolumn{8}{|l|}{ Development benefits } \\
\hline HEP production & 0 & 1 & 1 & 1 & 2 & 3 & 3 \\
\hline Crop production & 0 & 1 & 1 & 2 & 4 & 4 & 4 \\
\hline Water security & 0 & 1 & 2 & 3 & 4 & 5 & 5 \\
\hline National economy & 0 & 1 & 1 & 3 & 4 & 4 & 5 \\
\hline Aquaculture & 0 & 1 & 2 & 3 & 3 & 3 & 3 \\
\hline \multicolumn{8}{|l|}{ Development costs } \\
\hline Fish production & 0 & -1 & -1 & -1 & -2 & -4 & -5 \\
\hline Water quality & 0 & -1 & -3 & -4 & -4 & -5 & -5 \\
\hline Floodplain functions & 0 & -1 & -1 & -2 & -2 & -2 & -3 \\
\hline Cultural and religious use of river & 0 & -1 & -1 & -3 & -4 & -5 & -5 \\
\hline Compensation for lost resources & 0 & -1 & -2 & -2 & -3 & -3 & -4 \\
\hline
\end{tabular}

advise with incomplete knowledge, they must be able to enhance their understanding at the same time. Otherwise a country continues to live on its scant knowledge capital, possibly making the same poor management decisions over and over again.

Monitoring programs are most likely to be funded by water managers if they are modest in size. Parsimonious monitoring programs have been designed that provide a first alert to possible change and require the measurement of only a few indicators that have been carefully selected to represent a far wider array of ecosystem functions (Table 11). For example, habitat-flow maps of river sites (King et al. 2003) can be redrawn and entered into a GIS once every 3-5 yr to assess if major sedimentological, geomorphological, or physical habitat changes are occurring and if habitat diversity is being lost. Annual bioassessment of the aquatic invertebrate community (Chutter 1994) would indicate if major water quality changes were occurring, and annual or less frequent surveys of the fish and plant communities provide insights into larger-scale ecosystem conditions.

Scientists in Kruger National Park (KNP) strengthened their monitoring approach by developing an objectives hierarchy that defines their management objectives for KNP rivers. This describes objectives at all levels, from the overall vision of what they want to achieve, i.e., the top level of the hierarchy, to individual goals at the 
Table 11. Template for an environmental flow monitoring program designed for the Lesotho Highlands Water Project (modified from LHDA 2003). The zones include the aquatic, lower wetbank, upper wetbank, lower dynamic, and tree/shrub zones (Metsi Consultants 2000a).

\begin{tabular}{|c|c|c|c|c|c|}
\hline \multirow[t]{2}{*}{ Indicator } & Category A & Category B & Category C & Category D & $\begin{array}{l}\text { Category E/ } \\
\text { F }\end{array}$ \\
\hline & Pristine & $\begin{array}{l}\text { Near nat- } \\
\text { ural }\end{array}$ & $\begin{array}{l}\text { Moderately } \\
\text { modified }\end{array}$ & $\begin{array}{l}\text { Significa- } \\
\text { ntly } \\
\text { modified }\end{array}$ & $\begin{array}{l}\text { Severely } \\
\text { modified }\end{array}$ \\
\hline \multicolumn{6}{|c|}{$\begin{array}{l}\text { Geomorphology } \\
\text { /hydraulics }\end{array}$} \\
\hline $\begin{array}{l}\text { Instream } \\
\text { habitat } \\
\text { diversity }\end{array}$ & $\begin{array}{l}\text { Full natural } \\
\text { diversity }\end{array}$ & $5-15 \%$ loss & $\begin{array}{l}15-40 \% \\
\text { loss }\end{array}$ & $\begin{array}{l}40-70 \% \\
\text { loss }\end{array}$ & $\begin{array}{l}>70 \% \\
\text { loss }\end{array}$ \\
\hline $\begin{array}{l}\text { Pool } \\
\text { depth }\end{array}$ & Natural & $5-15 \%$ loss & $\begin{array}{l}15-40 \% \\
\text { loss }\end{array}$ & $\begin{array}{l}40-70 \% \\
\text { loss }\end{array}$ & $\begin{array}{l}>70 \% \\
\text { loss }\end{array}$ \\
\hline $\begin{array}{l}\text { Bank } \\
\text { area eroded } \\
\text { or collap- } \\
\text { sed }\end{array}$ & $<5 \%$ & $5-10 \%$ & $10-20 \%$ & $20-40 \%$ & $>40 \%$ \\
\hline \multicolumn{6}{|c|}{ Water quality } \\
\hline $\begin{array}{l}\text { Change } \\
\text { in mean } \\
\text { monthly } \\
\text { temperat- } \\
\text { ure }\end{array}$ & Natural & $<3^{\circ}$ & $<4^{\circ}$ & $<5^{\circ}$ & $<6^{\circ}$ \\
\hline $\begin{array}{l}\text { Change } \\
\text { in annual } \\
\text { pH range }\end{array}$ & Natural & $\begin{array}{l}<0.5 \mathrm{pH} \\
\text { units }\end{array}$ & $\begin{array}{l}<1.0 \mathrm{pH} \\
\text { units }\end{array}$ & $\begin{array}{l}<1.5 \mathrm{pH} \\
\text { units }\end{array}$ & $\begin{array}{l}<2 \mathrm{pH} \\
\text { units }\end{array}$ \\
\hline $\begin{array}{l}\text { Total } \\
\text { Rapid Bi- } \\
\text { ological } \\
\text { Assessm- } \\
\text { ent (SASS) } \\
\text { Score }\end{array}$ & Unknown & $>95$ & $94-70$ & $69-45$ & $<45$ \\
\hline \multicolumn{6}{|l|}{ Vegetation } \\
\hline $\begin{array}{l}\text { Zone } \\
\text { definition }\end{array}$ & $\begin{array}{l}\text { All present } \\
\text { and distinct }\end{array}$ & $\begin{array}{l}\text { All present } \\
\text { and distinct }\end{array}$ & $\begin{array}{l}\text { Loss of < } \\
2 \text { zones } \\
\text { and/or zone } \\
\text { definition } \\
\text { less distinct }\end{array}$ & $\begin{array}{l}\text { Loss of < } \\
3 \text { zones } \\
\text { and/or zone } \\
\text { definition } \\
\text { indistinct }\end{array}$ & $\begin{array}{l}\text { No definit- } \\
\text { ion }\end{array}$ \\
\hline $\begin{array}{l}\text { Species } \\
\text { composit- } \\
\text { ion of } \\
\text { riparian } \\
\text { vegetation }\end{array}$ & $\begin{array}{l}\text { Full com- } \\
\text { plement }\end{array}$ & $\begin{array}{l}\text { Change in } \\
\text { ratios of } \\
\text { indigenous } \\
\text { species }\end{array}$ & $\begin{array}{l}\text { Dominated } \\
\text { by hardy } \\
\text { indigenous } \\
\text { species a- } \\
\text { nd/or ex- } \\
\text { otic species }\end{array}$ & $\begin{array}{l}\text { Dominated } \\
\text { by exotics } \\
\text { and/or w- } \\
\text { eedy indi- } \\
\text { genous s- } \\
\text { pecies }\end{array}$ & $\begin{array}{l}\text { Dominated } \\
\text { by one or } \\
\text { two species, } \\
\text { often > } \\
80 \% \text { exotics } \\
\text { OR no } \\
\text { plants }\end{array}$ \\
\hline
\end{tabular}




\begin{tabular}{|c|c|c|c|c|c|}
\hline $\begin{array}{l}\text { Growth } \\
\text { forms }\end{array}$ & $\begin{array}{l}\text { Full array } \\
\text { of growth } \\
\text { forms }\end{array}$ & $\begin{array}{l}5-10 \% \text { r- } \\
\text { eduction }\end{array}$ & $\begin{array}{l}11-25 \% \\
\text { reduction }\end{array}$ & $\begin{array}{l}26-50 \% \\
\text { reduction }\end{array}$ & $\begin{array}{l}>50 \% \\
\text { reduction }\end{array}$ \\
\hline \multicolumn{6}{|l|}{ Fish } \\
\hline $\begin{array}{l}\text { Commu- } \\
\text { nity com- } \\
\text { position }\end{array}$ & $\begin{array}{l}\text { Full com- } \\
\text { plement of } \\
\text { native sp- } \\
\text { ecies in } \\
\text { natural p- } \\
\text { roportions; } \\
\text { no exotic } \\
\text { species }\end{array}$ & $\begin{array}{l}\text { Full com- } \\
\text { plement of } \\
\text { native sp- } \\
\text { ecies, plus } \\
\text { very low } \\
\text { numbers of } \\
\text { exotic sp- } \\
\text { ecies }\end{array}$ & $\begin{array}{l}\text { Noticeable } \\
\text { shifts in } \\
\text { structure of } \\
\text { native fish } \\
\text { commun- } \\
\text { ity, mod- } \\
\text { erate nu- } \\
\text { mbers of } \\
\text { exotic sp- } \\
\text { ecies }\end{array}$ & $\begin{array}{l}\text { Very few } \\
\text { native fish } \\
\text { species a- } \\
\text { nd/or ex- } \\
\text { otic } \\
\text { fish dom- } \\
\text { inate }\end{array}$ & $\begin{array}{l}\text { Very few } \\
\text { fish species, } \\
\text { dominated } \\
\text { by exotic } \\
\text { species }\end{array}$ \\
\hline
\end{tabular}

lowest level, i.e., what is actually measured (Rogers et al. 2000). Thresholds of Probable Concern (TPCs) are set that identify unacceptable changes in river condition, and the range of values within which the measurements for each should fall is defined. In the Sabie River, for instance, TPCs are being used to reveal if there is a directional loss of bedrock or a change in the age structure of a certain tree species; these features are both indicators of wider river degradation (Rogers and Biggs 1999).

The indicators in the DRIFT-SOLVER software package act in much the same way as TPCs. Through their severity ratings of predicted change, they provide values of acceptable and unacceptable change, in terms of what has been agreed upon as the desired state of the river, against which monitoring results can be compared. For the Palmiet River in the Western Cape, for example, the desired state is that of a B/C Category river (Table 8). The limits of allowable change for a $\mathrm{B} / \mathrm{C}$ condition could be gleaned from the flow-response couplets for the Palmiet within DRIFT-SOLVER (Table 12) and used to assess monitoring results.

\section{Implementation and adaptive management}

The implementation of agreed-upon EFs is the most difficult part of the whole sequence. If EF monitoring is to be an effective part of an implementation plan, management structures need to be able to manage heterogeneity, test the efficacy of their practices, and react to monitoring results that reveal that unacceptable change is occurring. Adaptive management is difficult for large government or other organizations, which tend to be prescriptive with rigid rules. A culture needs to be developed that facilitates response to findings from monitoring programs, otherwise reports could be written and recommendations made to no effect.

\section{Supporting research}

The above process pushes specialists in many fields to the edge of their knowledge and experience, and sometimes beyond. The willingness of river scientists to step forward to this high-risk point should be balanced by a comprehensive investment in research on flow-ecosystem relationships. A mere $1 \%$ of the cost of developing a new water resource would fund an extensive research program on a targeted river, but even this modest investment is usually seen as too costly. Without a structured and comprehensive research investment program, a country is likely to continue to operate largely on present knowledge, which is inadequate for holistic management of this most limiting of natural resources.

The link from predictions of river change to predictions of impact on livelihoods is weak, largely because few social specialists and resource economists have tried to understand the language of river scientists in the way that these scientists have learned the language of engineers and water managers. Mitigation and compensation costs can be contentious at the best of times, a situation that 
Table 12. Resource quality objectives for riparian vegetation categorized as B/ $\mathrm{C}$ for the lower Palmiet River, Western Cape (modified from Boucher and Tlale 2000). For an explanation of the categories, please see Table 8.

\begin{tabular}{lll}
\hline \hline $\begin{array}{l}\text { Riparian vegetation } \\
\text { zone }\end{array}$ & $\begin{array}{l}\text { Requirement for } \\
\text { the lower } \\
\text { Palmiet } \\
\text { to be a B/C river }\end{array}$ \\
& \\
\hline
\end{tabular}

Aquatic

Marginal

Transitional

Dry

General
Aponogeton spp. and algae $<10 \%$ cover

Sandy deposits colonized by herbaceous species, not shrubs or trees

Rocky sills support sexually reproducing Isolepis digitata

No bank

collapse

No bank

collapse

No invasion by woody exotic species

Native woody perennials dominate Alien invasive species limited to $<5$

individuals $/ 10 \mathrm{~m}^{2}$ Post-fire recruitment dominated by woody native perennials

No native riparian plant species should become extinct from the reach or dominate the community
Densities will increase if winter floods are not provided.

If there are constant high flows, I. digitata will not reproduce, and if there are constant low flows, it will only reproduce vegetatively.

Present clearing of alien invasive trees must continue.

Dramatic changes in species content and density should be explored and explained. 
is exacerbated by $\mathrm{EF}$ assessments (EFAs) based on low-confidence scientific predictions. Social and economic specialists are needed who are interested in EFAs and willing to develop the necessary techniques and skills.

\section{CONCLUSION}

Environmental flow assessments (EFAs) are part of a new, comprehensive approach to water resource management that can guide more sustainable use of rivers. Because they provide new information not previously available to decision makers, they can empower and inform decision making. The EFA approach makes river condition a priority management issue (Watson 2006) and requires water managers to become holistic managers of aquatic ecosystems. EFAs should be done early in the planning process of water development, together with an analysis of the economic benefits of the proposed scheme, so that the agreed trade-off between development benefits and natural resource degradation can guide project design and operation. Stakeholders from a wide range of disciplines should feed in to the final government decision with regard to trade-offs: at present, the trend is that the probable losers in development schemes, e.g., those who live closest to the river geographically and require it for subsistence, are largely ignored in favor of those who benefit, e.g., urban areas that gain electricity and water. When an EFA is implemented, institutions should aim to manage heterogeneity, ensure the strong transfer of environmental flow concepts from central government offices to regional implementing offices, and develop adaptive management strategies. Implementation is not an issue for managers alone; scientists need to work side by side with managers to help ensure its success.

Responses to this article can be read online at: http://www.ecologyandsociety.org/voll1/iss2/art26/responses/

\section{Acknowledgments:}

This paper was presented at the Second International Symposium on Riverine Landscapes, Bredsel, Sweden, in August 2004. Many thanks to the organizers Christer Nilsson and Roland Jansson of Umea University for the invitation and for their kind help with editing the manuscript.

\section{LITERATURE CITED}

Arthington, A. H., S. O. Brizga, S. C. Choy, M. J. Kennard, S. J. Mackay, R. O. McCosker, J. L. Ruffinin, and J. M. Zalucki. 2000. Environmental flow requirements of the Brisbane River downstream from Wivenhoe Dam. South East Queensland Water Corporation and Centre for Catchment and In-stream Research, Brisbane, Australia.

Arthington, A. H., J. L. Rall, M. J. Kennard, and B. J. Pusey. 2003. Environmental flow requirements of fish in Lesotho rivers using the DRIFT methodology. River Research and Applications 19:641-666.

Boucher, C. 2002. Flows as determinants of riparian vegetation zonation patterns in selected southern African rivers. Available online at: http:// 72.14.203.104/search?q=cache:wLVM47T0mQ8J: www.uidaho.edu/ecohydraulics/faculty/klausjorde/ c-town/Proceedings/Boucher/BoucherText.PDF+Bouchert \%22Flows+as+determinants+of+riparian\%22\&hl= en\&gl=ca\&ct $=$ clnk\&cd=1.

Boucher, C. and S. Tlale. 2000. Vegetation. Metsi Report No. LHDA 648-F-16. Lesotho Highlands Development Authority, Maseru, Lesotho.

Brizga, S. O., A. H. Arthington, S. C. Choy, M. J. Kennard, S. J. Mackay, B. J. Pusey, and G. L. Werren. 2002. Benchmarking, a "top-down" methodology for assessing environmental flows in Australian rivers. In Proceedings of environmental flows for river systems. (Cape Town, 2002). Southern Waters Consulting, Cape Town, South Africa.

Brown, C. A., and A. Joubert. 2003. Using multicriteria analysis to develop environmental flow scenarios for rivers targeted for water resource development. Water SA 29:365-374.

Brown, C. A., and J. M. King. 2002. Breede River Basin Study: DRIFT application. Water Research Commission, Pretoria, South Africa.

Brown, C. A., A. Sparks, and G. Howard. 2000. Assessment of the instream flow requirements for the Palmiet River and the freshwater requirements for the Palmiet Estuary. In Proceedings of the IFR Workshop and determination of associated dam yields. DWAF Consultancy Report No. G400-00-0499. Department of Water Affairs and Forestry, Pretoria, 
South Africa.

Chutter, F. M. 1994. Research on the rapid biological assessment of water quality impacts in streams and rivers. WRC Report No. 422/1/98. Water Research Commission, Pretoria, South Africa.

Department of Water Affairs and Forestry (DWAF). 1999. Palmiet River, Western Cape; determination of resource directed measures. DWAF, Pretoria, South Africa.

Department of Water Affairs and Forestry (DWAF). 2004. Thukela Water Management Area: reserve determination; Thukela main report. Report No. PBV000-00-10315. Institute for Water Research/Source-to-Sea, Pretoria, South Africa.

Department of Water Affairs and Forestry (DWAF). 2005. The development of a national water resource classification system. ESJ Dollar Consulting, Cape Town, South Africa.

Dollar, E. S. J. 2003. Elands Catchment Reserve assessment study, Mpumalanga Province, final inception report. Report No. ENV-P-C 2003-028. Council for Scientific and Industrial Research, Pretoria, South Africa.

Dollar, E. S. J. 2005. Geomorphology. In C. Brown and C. Pemberton, editors. Olifants-Doring Catchment ecological water requirements study. Riverine RDM report. Volume 1: specialistreference reports. Report No. RDM/V1/SRR/01/CON/0505. Department of Water Affairs and Forestry, Pretoria, South Africa.

King, J., C. Brown, and H. Sabet. 2003. A scenario-based holistic approach to environmental flow assessments for rivers. River Research and Applications 19:619-639.

King, J. M., and D. Louw. 1998. Instream flow assessments for regulated rivers in South Africa using the Building Block Methodology. Aquatic Ecosystems Health and Restoration 1:109-124.

King, J. M., R. E. Tharme, and M. S. de Villiers, editors. 2000. Environmental flow assessments for rivers: manual for the Building Block Methodology. WRC Report TT 131/00. Water Research Commission, Pretoria, South Africa.
Kleynhans, C. 1999. A procedure for the determination of the ecological reserve for the purposes of the national water balance model for South African rivers. Department of Water Affairs and Forestry, Pretoria, South Africa.

Lesotho Highlands Development Authority (LHDA). 2003. Procedures for the implementation of the LHWP Phase 1 Instream Flow Requirements Policy. LHDA, Maseru, Lesotho.

Malan, H. L., and J. A. Day. 2002. Developing numerical methods for predicting relationships between stream flow, water quality and biotic responses in rivers. WRC Report No. 956/1/02. Water Research Commission, Pretoria, South Africa.

McCully, P. 1996. Silenced rivers: the ecology and politics of large dams. Zed Books, London, UK.

Metsi Consultants. 2000a. Consulting services for the establishment and monitoring of instream flow requirements for river courses downstream of LHWP dams; LHDA 648 specialist report: vegetation. Report no. LHDA 648-F-16. Lesotho Highlands Development Authority, Maseru, Lesotho.

Metsi Consultants. 2000b. Consulting services for the establishment and monitoring of instream flow requirements for river courses downstream of LHWP dams; LHDA 648 final report: summary of main findings. Report no. LHDA 648-F-16. Lesotho Highlands Development Authority, Maseru, Lesotho.

Metsi Consultants. 2000c. Consulting services for the establishment and monitoring of instream flow requirements for river courses downstream of LHWP dams; LHDA 648 specialist report: sedimentology. Report no. LHDA 648-F-14. Lesotho Highlands Development Authority, Maseru, Lesotho.

Metsi Consultants. 2000d. Consulting services for the establishment and monitoring of instream flow requirements for river courses downstream of LHWP dams; LHDA 648 specialist report: water quality. Report no. LHDA 648-F-15. Lesotho Highlands Development Authority, Maseru, Lesotho.

Metsi Consultants. 2000e. Consulting services for 
the establishment and monitoring of instream flow requirements for river courses downstream of LHWP dams; LHDA 648 specialist report: macroinvertebrates. Report no. LHDA 648-F-17. Lesotho Highlands Development Authority, Maseru, Lesotho.

Metsi Consultants. 2000f. Consulting services for the establishment and monitoring of instream flow requirements for river courses downstream of LHWP dams; LHDA 648 specialist report: sociology. Report no. LHDA 648-F-08. Lesotho Highlands Development Authority, Maseru, Lesotho.

Metsi Consultants. 2000g. Consulting services for the establishment and monitoring of instream flow requirements for river courses downstream of LHWP dams; LHDA 648 specialist report: public health. Report no. LHDA 648-F-09. Lesotho Highlands Development Authority, Maseru, Lesotho.

Metsi Consultants. 2000h. Consulting services for the establishment and monitoring of instream flow requirements for river courses downstream of LHWP dams; LHDA 648 specialist report: animal health. Report no. LHDA 648-F-10. Lesotho Highlands Development Authority, Maseru, Lesotho.

Ractliffe, S. G., and H. F. Dallas. 2004. Macroinvertebrates. In C. Brown and C. Pemberton, editors. Olifants-Doring catchment ecological water requirements study. Riverine RDM report. Volume 1: Specialist reference reports. Report No. RDM/V1/SRR/01/CON/0505. Department of Water Affairs and Forestry, Pretoria, South Africa.

Rogers, K., and H. Biggs. 1999. Integrating indicators, endpoints and value systems in strategic management of the rivers of the Kruger National Park. Freshwater Biology 41:439-451.

Rogers, K. H., D. J. Roux, and H. C. Biggs. 2000. Challenges for catchment management agencies: lessons from bureaucracies, business and resource management. Water SA 26:505-511.

Steward, H. J., E. K. Madamombe, and C. C. Topping. 2002. Adapting environmental flow methodologies for Zimbabwe. In Proceedings of environmental flows for river systems. (Cape Town, 2002). Southern Waters Consulting, Cape Town,
South Africa.

Tharme, R. E. 2003. A global perspective on environmental flow assessment: emerging trends in the development and application of environmental flow methodologies for rivers. River Research and Applications 19:397-396.

Watson, P. 2006. Manage the river as well as the dam: assessing environmental flow requirementslessons learned from the Lesotho Highlands Water Project. World Bank Directions in Development Series. World Bank, Washington, D.C., USA.

World Commission on Dams. 2000. Dams and development: a new framework for decisionmaking. Earthscan, London, UK. 